\title{
Development And Validation of A Customer Relationship Scale For Airline Companies
}

\author{
Gisela Demo ${ }^{\dagger}$ \\ Universidade de Brasilia \\ Kesia Rozzett ${ }^{\Omega}$ \\ Universidade de Brasilia \\ Natasha Fogaça ${ }^{¥}$ \\ Universidade de Brasilia \\ Taila Souza * \\ Universidade de Brasilia
}

\section{ABSTRACT}

Businesses with focus on customers through the use of Customer Relationship Management (CRM) perform better and win customer loyalty. Therefore, it is relevant to study the relationship between customers and airline companies, given that the aviation industry is highly competitive and relatively commoditized. Thus the aim of this study was to develop and validate a scale to measure customer's perception of relationship with airline companies. The scale was composed of four primary factors (customer loyalty, purchase experience, flight experience, and service) and a second order factor (customer relationship), all with good psychometric indices. The development and validation of a scale in an industry little explored by the CRM literature was the main contribution of this research, as it may be used as a diagnostic tool for airline companies to scale up their relationship with strategic customers and achieve more effective results.

Keywords: Customer relationship management; Airlines; Scale development and validation; Hierarchical factor analysis.

\section{INTRODUCTION}

Competition is a catalyst for pursuing excellence in business strategies, since it reflects directly in the business scenario by promoting consumption alternatives to an increasingly demanding market. According to Porter (1991), the competitive advantage is the result of the organization's ability to perform efficiently the set of activities necessary to obtain a lower cost than the competitors or to organize such activities in a unique way capable of generating a differentiated value for the clients. In this context, organizations should strive to offer greater value, either through better service, lower cost or greater quality in providing services to consumers in order to become more profitable and competitive. Relationship marketing is an evolution in the traditional concepts of Marketing when proposing a partnership between company and client, by offering personalized value that culminates in mutual benefits and increased profitability.

More specifically, the strengthening of these relationships between client and company should be studied in sectors where competition is fierce and the quality of the service and knowledge of preferences is a differential. In this context, the Brazilian airline sector, which is the third largest market in the world, with around 92 million domestic

Corresponding author:

† Universidade de Brasília

E-mail: giselademo@gmail.com

${ }^{\Omega}$ Universidade de Brasília

E-mail: kesiaro@gmail.com

${ }^{¥}$ Universidade de Brasília

E-mail: natasha.adm@gmail.com

* Universidade de Brasília

E-mail: tailacsouza@gmail.com

Received: 05/02/2016.

Revised: 08/03/2016.

Accepted: 10/31/2016.

Published Online: 11/01/2017. 
passengers. Between 2002 and 2013, the sector grew 208\% (BRAZILIAN ASSOCIATION AIRLINES [ABEAR], 2016), over 3.7 times the growth of the Brazilian gross domestic product (GDP) and more than 13 times the population growth, according to the National Civil Aviation Agency (Agência Nacional de Aviação Civil, 2014). However, the financial crisis that plagued the country since 2014 has produced its unfortunate effects also in civil aviation. Recent information published by the Brazilian Airlines Association (ABEAR, 2016), data from June 2016, show a 7\% decrease in transported passengers, $6.4 \%$ of supply decline and $5.9 \%$ fall in demand. The loss in the sector is estimated at 10 billion BRL from 2014 till the end of 2016 (DECEA, 2016).

Added to these statistics is the fact that passengers are increasingly dissatisfied with the services provided by airlines (CRAVO, 2014). Multiple problems are identified in the sector, such as flight delays and cancellations, faults in information provided to passengers, security breaches, among others. There is a lack of alternative in view of the insufficient rivalry to challenge dominant companies in airports.

Therefore, it is relevant to seek means and tools that help in the understanding of passengers' assessment of their relationship with airlines. Thus, the objective of this work is to develop and validate a scientific instrument to evaluate the relationship of the clients with the airlines. In addition, the perception of the sample surveyed is related to the relationship with airlines and their degree of satisfaction with them.

Understanding airlines as a complex domain of vast business reality, where multiple and diverse interests need to be aligned, a diagnostic tool allows managers to know the passengers' perception of their relationship with them, subsidizing decisions regarding the planning of services, pricing, and communication strategies, with the aim of promoting a better customer experience, which ultimately means, more effective organizational results.

\section{THEORETICAL FRAMEWORK}

Customer Relationship Management (CRM) is a business strategy that proposes managing customer relationships effectively in order to maintain competitiveness (PAYNE, 2012). Aiming at the prosperity of organizations and at optimizing their ability to reinvent themselves, relationships between organizations and clients acquire special connotation and CRM, encompassing aspects of customer satisfaction and loyalty, and especially the constant offer of unique and charming experiences, presents itself as a profitable differential (MISHRA; MISHRA, 2009; KUMARET AL., 2011).

Relationship marketing represents a paradigm shift of marketing concepts, by their greater focus on customer retention and loyalty and not just on the achievement (GRÖNROOS 1994; SHETH; SISODIA, 2002; PAYNE; 2012). In a practical way, it is necessary for the company to have integrated processes, operations and people so that the essence of relationship marketing can be the philosophy that guides the whole business (VAVRA, 1993).

Relationship marketing innovates by presenting a strategic vision of marketing concepts, advocating a shift from marketing orientation to customer acquisition (transactional) to focus on customer retention or loyalty (VAVRA, 1993). The author even suggests three factors as being the key components of the concept of relationship marketing or CRM, namely, quality, customer service and aftermarketing or customer loyalty strategies. In fact, there is a possibility of correlation between satisfaction, loyalty and relationship constructs, with quality, satisfaction and loyalty being possible components of a more comprehensive concept, namely the relationship with the customer (LEVITT, 1990; BOLTON, 1998).

Therefore, it is possible to admit that elements of quality, value, satisfaction and loyalty can be fundamental parts in the construction of a relationship and that, it is difficult for the business-client relationship to last if one of the parties is unhappy or unfaithful or disloyal to the other, as pointed out by LEVITT (1990). 
BBR

15,2

107

With its emergence in the 1990s, CRM quickly became a patent proposal of relevance. However, understanding what CRM means is still limited. Many companies do not understand CRM as a synonym for relationship marketing and see it as a technological solution, confusing customer relationship management with support systems for CRM implementation (MCKENNA, 1999).

Along the same lines, the empirical study conducted by Bygstad (2003) in a company that implemented CRM both as a marketing principle and as an information system revealed that CRM projects should be treated from a managerial perspective, focusing on marketing processes and the quality of information, with software tools being important for its implementation. These findings converge with the proposal by Zablah, Bellenger and Johnston (2004), by agreeing that the CRM literature is still inconsistent and highly fragmented due to the lack of a common conceptualization. Nevertheless, the authors advocate $\mathrm{CRM}$ as an ongoing process that involves developing customer relationships to optimize organizational results.

In Payne's (2012) view, it is true that CRM is a holistic strategic approach to managing customer relationships in order to create shareholder value. The author argues that CRM provides more opportunities for using data and information to understand the customer and better implement relationship marketing strategies, but this does not limit it to an information system or a technological tool. It is also emphasized that the importance of correctly defining CRM is not just a semantic preciosity.

In this context, in order for CRM to be successful, it needs to be imbued with a strategic vision to create shareholder value through the development of strategic customer relationships, linking the potential of information technology (IT) to relationship marketing strategies that will result in establishing long-term profitable relationships (PAYNE, 2012).

Therefore, from the conceptual framework thus designed, emerges the operational definition that will be adopted as reference in the present study, which understands Customer Relationship as a business strategy whose premise is customer focus, which should constitute the business philosophy of the company as a whole and that delivers superior value to customers through the quality of services provided, excellence in service and aftermarketing initiatives that translate into loyalty indicators. The scale proposed here will then evaluate the perception that customers have regarding the CRM initiatives undertaken by airlines (VAVRA, 1993; MCKENNA, 1999; ZABLAH; BELLENGER; JOHNSTON, 2004; PAYNE; STRORBACKA; FROW, 2008; PAYNE, 2012).

In an analysis of the relational benefits observed by service users, Mota and Freitas (2008) identified that customers have a positive outlook when they perceive that they get some special treatment, extra discount or priority service. In this sense, Souza Neto and Mello (2009) suggest that each service influences the nature of the relationship of the companies with their consumers in a different way and that it is important to consider that consumers are not all the same and each of them may wish for a different kind of relationship with the same company.

The recent empirical production shows that the implementation of CRM relies on the importance of trust, involvement, teamwork, innovation, flexibility, and focus on results to build a relationship-oriented corporate culture and the key role employees play in building long-lasting customer relationships, which generate greater value to organizations (IGLESIAS; SAUQUET; MONTAÑA, 2011; LOURENÇO; SETTE, 2013; GARRIDOMORENO, LOCKETT; GARCÍA-MORALES, 2014). In addition, proposals for innovative relationship marketing approaches in the context of e-CRM and social CRM have aroused the authors' interest (LENDEL; VARMUS, 2015).

Regarding CRM scales, some studies with scale validation based mainly on studies by Wilson and Vlosky (1997) and Sin, Tse and Yim (2005), aimed at the corporate market (B2B). Thus, with the intention of filling a gap in the literature regarding CRM measures 
for the consumer market (B2C), Rozzett and Demo (2010) conducted studies in Brazil and in the United States (DEMO; ROZZETT, 2013) to develop and validate a scale for the consumer market with the objective of evaluating clients' perceptions of their relationships with companies in general, which shows, ultimately, the clients' perception of the CRM initiatives undertaken by the companies. Some items in the scale by Rozzet and Demo (2010) and Demo and Rozzett (2013) served as the basis for the development of the scale proposed in this study.

Considering that diverse contexts demand specific indicators, from these studies, three custom scales have already been developed and validated in different sectors: amusement parks (VASCONCELOS; DEMO, 2012), electronic games (DEMO; BATELLI; ALBUQUERQUE, 2015) and beverages (DEMO; LOPES, 2014), but we found no study of relationship scales that focused on the commercial airline sector, constituting another gap in the literature.

As for the specific studies on airlines, we found research by Arruda and Arruda (1995) and Vasconcelos, Machado, Almeida, Arruda and Matos (2015). Arruda and Arruda (1995) analyzed the perception of passengers of Brazilian airlines regarding some attributes of the offered services that seemed fundamental for the image of the brand observed, aiming at their improvement and the loyalty of passengers. Overall, passengers positively assessed the attributes of airlines, but claimed that the ticket prices were high. The most frequently mentioned attributes were: loss of luggage, security, damaged luggage and on-board service. The authors recommended that companies improve aspects such as food, speed of baggage release, comfort and assistance with special requests.

In turn, Vasconcelos et al. (2015) analyzed the role of consumer experiences in brand image building, from the identification of the thoughts, feelings and actions resulting from the experiences of consumption with the airlines, and the types of associations that the consumer makes of such brands. The results indicated that thoughts, feelings and actions from consumer experiences become important elements in the image formation of airlines' brands. Consumers primarily use the attributes of the service to build their perceptions about airline brands.

\section{METHODS}

The performed research is classified as instrumental and descriptive, with a field research procedure, multi-method and cross-sectional in nature. To reach the objective, we performed two steps: the first refers to the qualitative study, with a survey of indicators to base the construction of the scale; and the second, the quantitative study, with scientific application and validation of the instrument.

\subsection{QUALITATIVE STUDY}

In this stage, we conducted interviews with airline employees and users. The number of participants was chosen in order to build a varied and representative group, respecting the criterion of saturation or completeness (BARDIN, 2013). Thus, we interviewed 27 participants, 18 users and nine airline employees chosen for convenience and accessibility. The users were 10 male clients and 8 female clients, with an average age of 32 years $(\sigma=14)$. The employees were five women and four men, also with an average age of 32 years $(\sigma=11)$. The average length of service in the role was nine years $(\sigma=12)$, with an extreme case of an airport agent for 34 years in the role.

Participants received an invitation with detailed research and signed a consent and authorization. The interview was unstructured and directed, with two questions, one for employees and managers and the other for users, respectively: 1) "What aspects do you consider relevant to develop a good relationship with your customers considering satisfaction 
BBR

15,2

and loyalty?"; 2) "What aspects do you consider relevant to develop a good relationship with airlines, considering their satisfaction and loyalty?". Before the questions, we clarified to the respondents that the concept of relationship adopted was that by Vavra (1993), with its three dimensions.

Next, we performed a thematic content analysis (BARDIN, 2013).

\subsection{QUANTITATIVE STUDY}

In the second step, we created scale items based on the results of the interviews conducted and on the Customer Relationship Scale (CRS), validated in Brazil (ROZZETT; DEMO, 2010) and in the United States (DEMO; ROZZETT, 2013).

The pilot instrument was submitted to semantic analysis, as recommended by Kerlinger and Lee (2008), in which 23 airline users have compared the clarification of the items. We also submitted to the judge analyzes, in which eight experts on the subject analyzed whether the proposed items referred to the relationship construct and were appropriate for consumers of the airline services.

The instrument was applied online through Typeform for airline customers who travel at least once a year and are over 18 years of age. In total, we collected 512 questionnaires.

We used non-probabilistic sampling for convenience due to the infinity tendency of the passenger population of airlines (COCHRAN, 1977) and the cost and time of the research. We observed the criteria by Pasquali (2012) and Tabachnick and Fidell (2013) for research with multivariate data analysis, of at least 200 to 300 subjects or 5 to 10 cases per item of the instrument. We applied 512 questionnaires on a scale of 54 items, thus meeting all criteria.

The data were analyzed through descriptive measures and Exploratory Factor Analysis using the Statistical Package for Social Sciences program (SPSS, version 22).

Prior to the analyzes, we performed the data coherence inspection and treated the lacking and missing cases. We used the listwise procedure for missing data and the Mahalanobis distance method for extreme data (TABACHNICK; FIDELL, 2013). At the end of this stage 93 questionnaires were removed.

Regarding the assumptions for the use of multivariate analysis, we verified the existence of normality, homoscedasticity and linearity, as well as multicollinearity and singularity (HAIR; BLACK; BABIN; TATHAM, 2009). The data returned acceptable values for the standards proposed by Hair et al. (2009).

Finally, the sample had 419 subjects, who met the statistical criteria for sample determination and even exceeded the minimum necessary to have representativeness in populations considered as infinite.

The 419 subjects who composed the final sample were from 18 Brazilian states (29\%) and from Distrito Federal (71\%), distributed evenly according to genre (50.2\% of men and $49.8 \%$ of women), aged between 18 and 28 years old (75\%) and complete higher education $(51 \%)$.

The company most evaluated was TAM (41.9\%), followed by GOL (36.6\%), Azul (12\%) and Avianca (6.0\%). Air France, American Airlines, Delta Airlines, Copa Airlines, Easyjet and Jal totaled $3.6 \%$ of the above companies.

Almost half of the respondents have been clients of the company chosen between one and five years ago (48\%). Only $5 \%$ of the sample has been a client for less than a year, which is favorable for the results, since clients with greater time of relationship may be more apt to make judgments on the attributes of the good or service offered. 


\section{RESULTS AND DISCUSSION}

The interviews were transcribed and the data were then analyzed and classified into themes, which were counted according to their frequency. These themes comprised categories of analysis and based the creation of the items for the questionnaire which was applied in the quantitative stage. Table 1 summarizes the content analysis.

From the scales by Rozzett and Demo (2010) and Demo and Rozzett (2013) and after the content analysis, the items of the questionnaire were created, based on the themes and categories found, which were submitted to theoretical validation - semantic and judge analysis - as recommended by Kerlinger and Lee (2008).

The semantic analysis had the participation of 23 respondents of varied profile in order to evaluate the clarity of the items and reduce possible doubts in the application of the research. Simultaneously, an analyzes by judges with eight specialists in the subject was conducted, among masters, doctoral students and doctors, with the objective of conferring the pertinence of the items in relation to the theoretical concepts.

Initially, the questionnaire had 61 items on client-company relationship and six sociodemographic questions. At the end of the theoretical validation, 12 items were excluded, eight modified and five added by evaluators' suggestions. The application version counted 54 items evaluated by the Likert scale, six socio-demographic questions and one item to measure customer satisfaction with the company, according to the Net Promoter Score.

After applying the questionnaires and data treatment, we carried out an analysis of the main components to verify the factorability of the matrix, adequacy of the sample and determination of the quantity of factors.

The inspection of the correlation matrix, the values of commonality (the majority above $0.6)$ and the Kaiser-Meyer-Olkin index (KMO) of 0.94 indicated high matrix factorization (KAISER, 1974).

In order to identify the number of factors of the instrument, we used eigenvalues as a choice criteria above 1.0 , the percentage of explained variance greater than $3 \%$, the inflection point in the screeplot graph and the parallel analysis. The eigenvalues indicated 10 factors and that of the total variance five, while the visual analysis of the screeplot indicated six factors. On the other hand, the parallel analysis, considered the most reliable for the determination of the quantity of factors (HAYTON; ALLEN; SCARPELLO, 2004), indicated five. However, in theoretical terms, there was no support for the existence of five factors and we decided, therefore, to establish the analysis in four factors.

Then, we performed an analysis of the main axes with oblique promax rotation and minimum acceptable loading of 0.45 (PASQUALI, 2012; TABACHNICK; FIDELL, 2013).

The high correlation between the factors (above 0.3 ) suggested the possibility of second order factors (PASQUALI, 2012). Thus, the four factors extracted were resized as latent indicators of a second order general factor and a new analysis of main components was performed, pointing to a factor, as expected.

The scale resulted in four first-order factors, termed as "Purchasing Experience", "Flight Experience", "Customer Loyalty" and "Customer Service", consistent with the content analysis and proposed theory, and a general second-order factor called "Customer Relationship", formed by the four first order factors identified.

Table 2 shows the first order factors and their factor loadings in the second order factor. The Customer Loyalty factor can be considered the best representative or the most central 
Table 1. Result of content analysis

\begin{tabular}{|c|c|c|c|}
\hline Verbalization of relevant aspects & Theme & Category & $\begin{array}{c}\text { Fre- } \\
\text { quency }\end{array}$ \\
\hline $\begin{array}{l}\text { "I think that firstly I would define price, without a doubt, price and } \\
\text { payment terms, if it can be divided into installments, and how many } \\
\text { payments" } \\
\text { "Today the price is enough, the cheaper the ticket, for me the better." }\end{array}$ & Payment & \multirow{3}{*}{$\begin{array}{l}\text { Purchasing } \\
\text { Experience }\end{array}$} & $\begin{array}{c}15 \\
(56 \%)\end{array}$ \\
\hline $\begin{array}{l}\text { "also the cost-benefit ratio, buying at a good value and traveling at } \\
\text { good hours" } \\
\text { "The first thing I look for in an airline is the price and availability of } \\
\text { flights made clear, to the destination I want and at the times I want" } \\
\text { "you'll end up in a company that meets your schedule needs" }\end{array}$ & $\begin{array}{l}\text { Time op- } \\
\text { tions }\end{array}$ & & $\begin{array}{c}4 \\
(15 \%)\end{array}$ \\
\hline $\begin{array}{l}\text { "but also, issues of ease in buying the ticket over the internet" } \\
\text { "Ease when buying the ticket on the internet, because I only bought } \\
\text { on the internet, for years" }\end{array}$ & $\begin{array}{l}\text { Purchase } \\
\text { Facility }\end{array}$ & & $\begin{array}{c}4 \\
(15 \%)\end{array}$ \\
\hline $\begin{array}{l}\text { "Well, to my satisfaction, I think it's meeting the scheduling of airli- } \\
\text { nes" } \\
\text { "I think it's important to be punctual" }\end{array}$ & Punctuality & \multirow{6}{*}{$\begin{array}{l}\text { Travel ex- } \\
\text { perience }\end{array}$} & $\begin{array}{c}12 \\
(44 \%)\end{array}$ \\
\hline $\begin{array}{l}\text { "You arrive at the airport and you can check in quickly" } \\
\text { "the fact that people can check in by cell phone" } \\
\text { "provide check-in conditions" }\end{array}$ & $\begin{array}{l}\text { Agility at } \\
\text { check-in }\end{array}$ & & $\begin{array}{c}7 \\
(26 \%)\end{array}$ \\
\hline $\begin{array}{l}\text { "I think the stools are too tight" } \\
\text { "Comfort while traveling is also very important" } \\
\text { "The main items, attributes that I can cite, is convenience and servi- } \\
\text { ce" }\end{array}$ & $\begin{array}{c}\text { Convenien- } \\
\text { ce }\end{array}$ & & $\begin{array}{c}8 \\
(30 \%)\end{array}$ \\
\hline $\begin{array}{l}\text { "to provide security and luggage control" } \\
\text { "due care with luggage integrity" } \\
\text { "the main thing is they do the basics that they have to do right, } \\
\text { which is not to lose my luggage, my luggage has already been lost } \\
\text { countless times" }\end{array}$ & $\begin{array}{l}\text { Due care } \\
\text { with bagga- } \\
\text { ge integrity }\end{array}$ & & $\begin{array}{c}3 \\
(11 \%)\end{array}$ \\
\hline $\begin{array}{l}\text { "for the air conditioner to be working in the cabin so one does not } \\
\text { get sweaty" } \\
\text { I think that the main point of any airline is to ensure safety" }\end{array}$ & $\begin{array}{l}\text { Good In- } \\
\text { frastructure }\end{array}$ & & $\begin{array}{c}7 \\
(26 \%)\end{array}$ \\
\hline $\begin{array}{l}\text { "on-board service in a differentiated way because it can retain custo- } \\
\text { mer loyalty" } \\
\text { "when you ask for something, now that it is paid, that the food is } \\
\text { served hot and the drink cold" }\end{array}$ & $\begin{array}{l}\text { On board } \\
\text { service }\end{array}$ & & $\begin{array}{c}3 \\
(11 \%)\end{array}$ \\
\hline $\begin{array}{l}\text { "and the training of people to solve small or large problems" } \\
\text { "I had a reservation next to a window mark and I got there and they } \\
\text { only had corridor seats and it was an international trip, so it was } \\
\text { very unpleasant" } \\
\text { "When there are atypical situations that are not well solved by the } \\
\text { companies, then these companies end up losing credibility" }\end{array}$ & $\begin{array}{l}\text { Ability to } \\
\text { Solve Pro- } \\
\text { blems }\end{array}$ & \multirow{2}{*}{$\begin{array}{l}\text { Customer } \\
\text { service }\end{array}$} & $\begin{array}{c}11 \\
(41 \%)\end{array}$ \\
\hline $\begin{array}{l}\text { "Customer service, I think it is primal from the moment we enter the } \\
\text { airport, right?" } \\
\text { "Good service and empathy, we have to put ourselves in the } \\
\text { customer's shoes when we are working." } \\
\text { "But above all, what companies are prioritizing is good service." }\end{array}$ & $\begin{array}{l}\text { Good custo- } \\
\text { mer service }\end{array}$ & & $\begin{array}{c}24 \\
(89 \%)\end{array}$ \\
\hline
\end{tabular}


"And for loyalty, perhaps there is a flexibility of the airline with regard to rescheduling flights, greater ease for the customer. Today we have a lot of bureaucracy and high fees, right? There are several things to be done and everything one has to do needs to be paid for." "If I had to add one more point, they would be ways of loyalty, non-loyalty, ways of taking care of customers, for example: ease for rescheduling tickets."

"It is obvious that there are extras things, which is a loyalty program"

"Also having a loyalty program that is very advantageous for the most frequent customer."

"The only thing I also take into consideration are the loyalty programs right?" Accumulating miles, scoring."
Ease of res-

cheduling tickets 5

Customer loyalty

element of the construct underlying the general factor Customer Relationship, with 0.861 loading, and the factor Purchasing Experience would be the most peripheral element of the construct with loading of 0.481 .

According to Laros and Puente-Palácios (2004), the investigation of the presence of second order factors, based on the hierarchical factor analyzes, contributes to the understanding of the factorial structure of the scales allowing the theoretical development of the fields investigated by offering additional subsidies on the central and peripheral constituent elements of the constructs under study. We also evaluated the psychometric indexes of the scale in relation to item quality, reliability and total variance explained (HAIR ET AL., 2009).

The final version of the first-order solution from the Airline Customer Relationship Scale (CRS Airlines), after four iterations, was made up of 33 items: eight excellent, four very good, five good and 16 reasonable, according to the classification proposed by Comrey and Lee (1992). As for the second order solution, the customer relationship factor, after 11 iterations, was formed by four items: one reasonable, two very good and one excellent.

The degree of reliability of the scale (Cronbach's alpha) for the first-order factors and for the second-order factor was calculated and considered reliable (above 0.70 ) or very reliable (above 0.80), as shown in Table 3 (NUNNALLY; BERNSTEIN, 1994).

In addition, the first-order factors explained $44.6 \%$ of the construct variance, whereas the single factor of second order explained $59.4 \%$ of the variance. According to Hair et al (2009), variances explained around 50\% represent good factor solutions. Table 4 presents the items of the first order solution of the CRS of the Airlines with their respective factor loadings.

Notwithstanding the Airline CSR revealing good psychometric indexes, it is fundamental to verify its theoretical consistency to the construct "relationship perception", which, from the conceptual framework originating from Vavra (1993) and adopted in this study, should have dimensions similar to the quality of services, customer service and customer loyalty strategies.

Table 2. First order factors and their loadings on the second order factor

\begin{tabular}{lcc}
\hline Factor & Content & Loadings \\
\hline 1 & Customer Loyalty & 0.861 \\
4 & Customer Service & 0.685 \\
3 & Flight experience & 0.680 \\
2 & Purchasing experience & 0.481 \\
\hline
\end{tabular}


BBR

15,2

113

In a synthesized way, we can fit the factors "purchasing experience" (factor 2) and "flight experience" (factor 3) in a key element of "quality of the experience", because they measure the perception of customers as to the quality of services, information and ticket purchase options, as well as the provision of on-board services. According to Gupta and Vajic (2000), the service experience occurs when a consumer has some sensation or acquisition of knowledge resulting from a level of interaction with different elements of a context created by a service provider. In this context, aspects such as convenience and price are relevant (MOTA; FREITAS, 2008), which were also quite cited in the content analysis of the interviews conducted. They are the result of interactions between "the organization, its related systems/processes, its employees and consumers" (BITNER ET AL., 1997, p. 193). The emotional state of respondents, as a result of their interaction with the service attributes present in the experience, tends to influence their future purchasing behavior, giving evidence of the relationship between brand image and their preference (VASCONCELOS ET AL., 2015). These items had already been highlighted by Arruda and Arruda (1995), in a context different from the current one, but with similar items, such as "luggage loss", "damaged luggage", "speed of baggage release", "on-board service", "temperature/humidity inside the aircraft", "covers and pillows", "comfort" and "food". In the research by Vasconcelos et al. (2015), the interviewees used on-board services, service and punctuality of the flight as characteristics of the quality of services.

The factor "Customer Loyalty" (factor 1) presented items related to trust, identification with the brand, exceeding expectations, attitude and recommendation, which are relevant to the construction of a client's commitment to the company. According to Oliver (1999), loyalty is a deep-rooted commitment, associated with repeating purchases or a preference for a product or service over time, even if situational influences and efforts of competitors have the potential to cause exchange behavior. In this way, the development of strategies, programs and actions for the strengthening of loyalty is relevant.

The factor "Customer service" (factor 4) presented items that relate to the general presentation of the company (appearance), security and training of frontline employees. In this sense, employee training and commitment are highly relevant to the successful CRM implementation in a company (GARRIDO-MORENO; LOCKETT; GARCÍA-MORALES, 2014). The items such as "cleanliness of toilets", "security", "courtesy", "credibility" and "accurate answer to doubts" were relevant attributes for the satisfaction with airlines in the study by Arruda and Arruda (1995) and after twenty years are still of utmost importance to generate in the customer confidence to develop relationship with the company.

Although the item "I recommend this company to friends and family" being part of the factor "Customer loyalty", we added a question in the questionnaire in order to assess, from 0 to 10 , the likelihood of recommendation, according to the Net Promoter Score (NPS) (Reichheld, 2006). According to the author, the predisposition of a client to recommend the company, product or service is a consequence of the treatment that it receives when in contact with the front-line employees of the company. The higher the NPS, the greater

Table 3. Coefficients alpha $(\alpha)$ and number of items for the extracted factors

\begin{tabular}{lcc}
\hline Factor & Coefficient $\alpha$ & Number of items \\
\hline Customer Loyalty & 0.92 & 11 \\
Purchasing experience & 0.82 & 11 \\
Flight experience & 0.84 & 8 \\
Customer Service & 0.76 & 3 \\
Relationship with customers & 0.76 & 4 \\
\hline
\end{tabular}


Table 4. Description of the items and factor loadings of the first order solution

\begin{tabular}{|c|c|c|c|c|c|}
\hline Description & Firs & Order $\mathrm{F}$ & ctor Lo & & Quality \\
\hline & 1 & 2 & 3 & 4 & \\
\hline 1- This company deserves my trust. & 0.865 & & & & Excellent \\
\hline 2- I recommend this company to friends and family. & 0.848 & & & & Excellent \\
\hline 3- I feel like an important customer for this company. & 0.831 & & & & Excellent \\
\hline 5- I identify myself with this company/brand. & 0.789 & & & & Excellent \\
\hline 15- I have a positive image of this company. & 0.741 & & & & Excellent \\
\hline 6- This company treats me with respect. & 0.726 & & & & Excellent \\
\hline $\begin{array}{l}\text { 4- My travel experiences with this company exceed my } \\
\text { expectations. }\end{array}$ & 0.699 & & & & Very Good \\
\hline $\begin{array}{l}\text { 16- The advertising made by this company matches } \\
\text { what it actually offers. }\end{array}$ & 0.601 & & & & Good \\
\hline 7- This company offers me personalized service. & 0.532 & & & & Reasonable \\
\hline $\begin{array}{l}27-\text { This company is the best option compared to its } \\
\text { competitors in the market. }\end{array}$ & 0.521 & & & & Reasonable \\
\hline 10- This company seeks to know my preferences. & 0.468 & & & & Reasonable \\
\hline $\begin{array}{l}\text { 50- This company provides ticket/aerial miles promo- } \\
\text { tions. }\end{array}$ & & 0.652 & & & Very Good \\
\hline $\begin{array}{l}\text { 51- This company communicates with its customers } \\
\text { (e-mail, text message on mobile phone, mail). }\end{array}$ & & 0.632 & & & Very Good \\
\hline $\begin{array}{l}\text { 22- This company uses different customer service } \\
\text { channels such as face-to-face, telephone and internet. }\end{array}$ & & 0.605 & & & Good \\
\hline $\begin{array}{l}\text { 40- This company is part of a group of partner airlines, } \\
\text { offering passengers the option of flying to various des- } \\
\text { tinations. }\end{array}$ & & 0.596 & & & Good \\
\hline $\begin{array}{l}\text { 20- This company offers convenience to customers } \\
\text { through various check-in options (totems, applications, } \\
\text { website, counter). }\end{array}$ & & 0.554 & & & Good \\
\hline $\begin{array}{l}\text { 38- This company offers different time options for the } \\
\text { same destination. }\end{array}$ & & 0.539 & & & Reasonable \\
\hline $\begin{array}{l}\text { 29- This company offers benefits for loyal customers } \\
\text { (e.g.: advance boarding, priority check-in, VIP room). }\end{array}$ & & 0.522 & & & Reasonable \\
\hline $\begin{array}{l}\text { 41- This company has partnerships with other (e.g.: ho- } \\
\text { tels, car rental, insurance companies) to provide travel } \\
\text { convenience to customers. }\end{array}$ & & 0.493 & & & Reasonable \\
\hline $\begin{array}{l}\text { 48- This company offers customers several options of } \\
\text { ticket payment. }\end{array}$ & & 0.467 & & & Reasonable \\
\hline 19- This company's website meets my needs. & & 0.466 & & & Reasonable \\
\hline $\begin{array}{l}\text { 13- This company offers differentiated rates by seat and/ } \\
\text { or class. }\end{array}$ & & 0.450 & & & Reasonable \\
\hline $\begin{array}{l}\text { 36- The company's aircraft feature individual on-board } \\
\text { entertainment options (per seat). }\end{array}$ & & & 0.831 & & Excellent \\
\hline $\begin{array}{l}\text { 35- The aircrafts of this company have good entertain- } \\
\text { ment options on board. }\end{array}$ & & & 0.755 & & Excellent \\
\hline 42- Meals/snacks served on board are of high quality. & & & 0.619 & & Very Good \\
\hline $\begin{array}{l}\text { 34- I feel comfortable in this company's aircraft (space, } \\
\text { armchairs, cleaning, lighting, temperature). }\end{array}$ & & & 0.560 & & Good \\
\hline
\end{tabular}


32- This company has clear procedures of luggage return in case of luggage loss.

0.547

Reasonable

52- This company offers small gifts to delight custo-

mers (children's kit, jellybeans, headphones, birthday

0.519

Reasonable

cards).

31- This company cares about the integrity of my lug-

gage.

0.502

Reasonable

43- There is variety in the food/beverage options on

board, even if they are not free.

0.476

Reasonable

45- Overall, this company has a good appearance (employees, aircraft, service counters).

0.547 Reasonable

46- The crews/pilots of the company's flights transmit

safety to passengers, providing information during fli-

ghts.

0.535 Reasonable

47- This company's employees (on ground or on board)

appear to be well-trained to serve customers.

0.460 Reasonable

\begin{tabular}{llllll} 
Reliability & 0.92 & 0.82 & 0.84 & 0.76 \\
\hline Total Variance Explained & & & & & $44.60 \%$
\end{tabular}

the chance that the customer is developing a high degree of satisfaction with the company. In the research by Arruda and Arruda (1995), recommending the airline was positive and strongly correlated with credibility, accurate response to doubts, understanding of needs, assistance with special requests, prompt response to questions and courtesy.

The index for airlines in general was $13 \%$, with a positive emphasis for Azul (82\%) and Avianca (78\%) that reached similar NPS to Costco (79\%), company with the highest NPS in the United States in 2014, according to the Satmetrix research (DANSON, 2015). TAM (today known as LATAM) presented NPS with a common index of 10\%, and GOL, the second most cited company in the research, presented a NPS of $-33 \%$, indicating that there are more detractors than promoters among the GOL surveyed passengers.

In order to obtain an overview of customer perception, the items were analyzed through descriptive measures of central tendency and relative frequency of response. In relation to the Customer Loyalty Factor, the worst performing items were "This company seeks to know my preferences", "This company offers me personalized service" and "I feel like an important customer for this company".

According to Peppers, Rogers and Dorf(1999), the company can, in general, differentiate customers in two ways: by the levels of value they represent and by their distinct needs. From the identification of clients through variables related to habits, preferences, customs and personality, the differentiation of the client helps the company to gain greater advantage with its most valuable clients, as well as customize the behavior of the company for each client in order to reflect their values and needs. Consistently, Arruda and Arruda (1995, p. 32) found that "credibility and understanding of the needs are the attributes most taken into consideration by the passengers in the perception of quality of service".

Furthermore, the item "my travel experiences with this company exceed my expectations" also had weaker performance, indicating situations of positive customer disconfirmation. In this sense, it should be mentioned that, if the service is personalized, expectations can be met not only when the company offers exceptional service, but when it recovers a service. In this sense, Vasconcelos et al. (2015) found that experiences motivated by flight cancellations can also generate positive thoughts and pleasant feelings if the company goes beyond standard procedures. 
Concerning the perception of customers regarding "Purchasing Experience", we found that companies offer similar benefits, with ticket/aerial miles promotions, several options for check-in and different service channels. However, the item on partnerships with other establishments presented a weaker performance, close to point 3 , of indifference to the item. This may be an unknown aspect of customers and should be better communicated by airlines.

Regarding the "Flight Experience", the item with the best evaluation was "I feel comfortable in the aircraft of this company (space, seats, cleaning, lighting, temperature)". The item with the worst evaluation was "The company's aircraft feature individual on-board entertainment options (per seat)", which may have its low performance attributed to the characteristic of the sample, which responded to the survey considering domestic flights, which usually do not have individualized options.

According to Vasconcelos et al. (2015), the generation of positive or negative feeling is influenced by the experiences of buying and consuming, for example, due to the good quality of the on-board services offered by the company.

On the perception of customers regarding factor 4 "Customer service", the item with the highest evaluation was "Overall, this company has a good appearance (employees, aircraft, service counters)", and this suggests that the company's points of contact with the customer receive attention from the airlines. On the other hand, although item "The employees of this company (on-land or on-board) seem to be well-trained to serve customers" to be well evaluated, among the items of the care factor, was the one that received the worst evaluation, revealing that there may still be room for investment in the training of attendants in order to serve passengers in an increasingly excellent way.

In general, the results obtained outline a diagnosis of the perception that airline customers have regarding CRM initiatives. Highlights can assist in the design and implementation of market differentiation strategies that have a positive impact on establishing long-term customer relationships. In addition, the critical points require special attention on the part of managers in times of escalating competition.

\section{FINAL CONSIDERATIONS}

The present study had as its main objective the development and validation of a relationship scale with airline customers. The results gathered revealed that customers perceive CRM initiatives by airlines. Nevertheless, there are aspects that can be improved, such as knowledge of customer preferences, partnerships with other establishments and individualized on-board entertainment options.

O The instrument created was the Customer Relationship Scale airlines, composed of four first order factors, consistent with the literature and content analysis (customer loyalty, purchasing experience, flight experience and customer service) and a general second-order factor (client relationship), all with good psychometric indexes.

The main contribution of this study is the development of a valid and reliable operational measure, thus filling a gap in the literature regarding relationship marketing research in the B2C market, specifically in the civil aviation sector. In practical terms, the CRS Airlines can be used as a diagnostic tool for airline managers, since the results are able to reveal the perception of the clients regarding the CRM initiatives in the sector under study.

Regarding the limitations of the research, the cross-sectional nature of the study stands out, and the results obtained are specific to the sample and the moment of search, without the possibility of generalization. The online questionnaire was limited regarding its dissemination to the social networks of the researcher's contact. Furthermore, the proposed relationship scale with airline customers represents a first attempt to obtain a structure 
BBR

15,2

for this market, which must be confirmed later. Thus, the results are more indicative than conclusive.

For future research, we suggest validating this scale in different and more representative samples in terms of airlines that offer domestic flights and also with companies that offer international flights, with the purpose of increasing its external validity in terms of generalization and replicability. Discriminant analyzes of the relationship concept and its dimensions (quality, value, loyalty, satisfaction) are also welcome. Future CRS airline validations are recommended based on recent research that addresses new CRM trends, perspectives and changes in the airline business environment. Longitudinal studies can also provide a better refinement of the scale, by means of addition, modification and/or exclusion of items. In addition, testing the structure obtained so far through structural equation modeling is important to confirm the hierarchical exploratory model.

Considering the growing attention that researchers have given to the strategic role of CRM in organizations in competitive contexts, the present study offers a valid and reliable operational measure, tailored to the airline industry that can help managers improve their customer relationships and, ultimately, optimize organizational results.

\section{REFERENCES}

ASSOCIAÇÃO BRASILEIRA DAS EMPRESAS AÉREAS. Aviação brasileira: Agenda 2020. Recuperado de <http://www.abear.com.br/uploads/arquivos/dados_e_fatos_arquivos_ptbr/Agenda2020_ PORT_010714.pdf>.Agosto de 2016.

AGÊNCIĀ NACIONAL DE AVIAÇÃO CIVIL.Anuário do Transporte Aéreo 2013. Recuperado de<http:// www2.anac.gov.br/estatistica/anuarios.asp>. Outubro de 2014.

ARRUDA, M. C. C.; ARRUDA, M. L.Satisfação do cliente das companhias aéreas brasileiras. Revista de Administração de Empresas, v. 38, n.3, p. 25-33, 1998.

BARDIN, L. Análise de Conteúdo. Lisboa: Edições 70 LDA, 2013.DEMO, G; BATELLI, L.; ALBUQUERQUE, P. Customer Relationship Management Scale for Video Games' Players: Exploratory and Ordinal Factor Analysis. RevistaOrganizaçõesemContexto, v.11, n.22, p. 285-312, 2015.

BITNER, M. J.; FARANDA, W. T.; HUBBERT, A. R.; ZEITHAML, V. A. Customer contributions and roles in service delivery. International Journal of Service Industry Management, v. 8, n.3, p. 193-205, 1997.

BOLTON, R. N. A dynamic model of the duration of the customer's relationship with a continuous service provider: the role of satisfaction. Marketing Science, v. 17, n. 1, p. 45-65, 1998.

BYGSTAD, B. The implementation puzzle of CRM systems in knowledge-based organizations.Information Resources Management Journal, v. 16, n. 4, p. 33-45, 2003.

COCHRAN, W. G. Sampling Techniques, Terceira edição, New York: John Wiley\& Sons, Inc (1977).

COMREY, A. L.; LEE, H. B.A first course in factor analysis. 2. ed. New Jersey:Lawrence Erlbaum Associates, 1992.

CRAVO, B. M.A alocação de slots e a concorrência no setor de transporte aéreo. Journal of Transport Literature, v. 8, n. 1, p. 159-177, 2014.

DANSON, J. Costco, USAA, Amazon.com, and Apple Rank Among Highest for Customer Loyalty in Latest Satmetrix ${ }^{\circledR}$ Net Promoter Benchmarks.Recuperado de $<$ http://www.satmetrix.com/in-the-news/ costco-usaa-amazon-and-apple-rank-among-highest-in-customer-loyalty-in-latest-satmetrix-net-promoter-benchmarks/>. Março de 2015.

DEMO, G.; LOPES, C. Guaraná Antarctica e Cerveja Skol: Desenvolvimento e validação de escalas de relacionamento com clientes. In: Paulo Águas, Margarida Santos, Marisol Correia, \& Célia Ramos. (Eds.). Perspectivas Contemporâneas em Marketing.Portugal: TMS Conference Series, 183-199, 2014.

DEMO, G.; ROZZETT, K. Customer Relationship Management Scale for the Business to-Consumer Market: Exploratory and Confirmatory Validation and Models Comparison.International Business Research, v. 6, n. 11, 2013.

GARRIDO-MORENO, A.; LOCKETT, N.; GARCÍA-MORALES, V. Paving the way for CRM success: The mediating role of knowledge management and organizational commitment. Information \& Management, v. 51, n. 8,p. 1031-1052, 2014.

GRÖNROOS, C. From marketing mix to relationship marketing.Management Decision, v. 32, n. 2, p. 4-20, 1994. 
GUPTA, S.; VAJIC, M.The contextual and dialectical nature of experience, new service development, creating memorable experiences. New York: Sage, 2000.

HAIR, J. F.; BLACK, W. C.; BABI, B. J.; ANDERSON, R. E.; TATHAM, R. L. Análisemultivariada de dados. 6. ed. Porto Alegre: Bookman, 2009.

HAYTON, J. C.; ALLEN, D. G.; SCARPELLO, V. Factor retention decisions inexploratory factor analysis: a tutorial on parallel analysis. Organizational ResearchMethods, v. 7, n. 2, p.191-205, 2004.

IGLESIAS, O.; SAUQUET, A.; MONTAÑA, J.The role of corporate culture in relationship marketing, European Journal of Marketing, v, 45, n. 4,p. 631-650, 2011.

KAISER, H. F. An index of factorial simplicity.Psychometrika, v. 39, n. 1, p. 31-36,1974.

KERLINGER, F. N.; LEE, H. B. Foundations of behavioral research. 5 ed. Independence, KY: Wadsworth Thomson, 2008.KUMAR. V.; JONES, E.; VENKATESAN, R.; LEONE, R. P.Is market orientation a source of sustainable competitive advantage or simply the cost of competing? Journal of Marketing, v.75, n.1, p.16-30, 2011.

LAROS, J. A.; PUENTE-PALACIOS, K. E.Validação cruzada de uma escala de clima organizacional. Estudos de Psicologia, v. 9, n. 1, p. 113-119, 2004.

LENDEL, V.; VARMUS, M. Proposal of innovative approaches of relationship marketing in business.Business: Theory and Practice, v. 16, n. 1, p. 63-74, 2015.

LEVITT, T. A imaginação de marketing. 2. ed. São Paulo: Atlas, 1990.

LOURENÇO, C.; SETTE, R. Relacionamentos de Marketing em Empresas Varejistas: Aspectos Positivos e Negativos. Revista Brasileira de Marketing, v. 12, n. 3, p. 152-178, 2013.

MCKENNA, R. Marketing de relacionamento. Rio de Janeiro: Campus, 1999.

MISHRA, A.; MISHRA, D. Customer Relationship Management: implementation process perspective. Acta Polytechnica Hungarica, v. 6, n. 4,p. 83-99, 2009.

MOTA, M. O.; FREITAS, A. A. F. Análise dos benefícios relacionais observados por usuários de serviços. Revista deAdministração Mackenzie,v. 9, n. 6, p. 126-147, 2008.

NUNNALLY, J. C.; BERNSTEIN, I. H. Psychometric theory (3rd ed.).New York: McGraw-Hill,1994.

OLIVER, R. Whence Consumer Loyalty? Journal of Marketing, v. 63, n. 4, p. 33-44, 1999.

PASQUALI, L. Análise fatorial para pesquisadores. Laboratório de Pesquisa em Avaliação e Medida (LabPAM) - Instituto de Psicologia. Brasília: Universidade de Brasília, 2012.

PAYNE, A. Handbook of CRM: achieving excellence in customer relationship management. Oxford: Elsevier, 2012.

PAYNE, A.F.; STORBACKA, K.; FROW, P. Managing the Co-creation of Value.Journal of the Academy of Marketing Science, v. 36,n. 1, p. 83-96, 2008.

PEPPERS, D.; ROGERS, M.; DORF, B.Is your company ready for one-to-one marketing?Harvard Business Review,v. 77, n. 1, p. 151-160, 1999.

PORTER, M. E. Towards a dynamic theory of strategy. Strategic Management Journal, v. 12, n. S2, p. 95-117, 1991.

REICHHELD, F.The ultimate question: driving good profits and true growth. Boston: Harvard Business Review Press, 2006.

ROZZETT, K.; DEMO, G. Desenvolvimento e validação da Escala de Relacionamento com Clientes (ERC). Revista Administração de Empresas, São Paulo, v. 50, n. 4, p. 383-395, out./dez., 2010.

SHETH, J. N.; SISODIA, R. S. Marketing productivity: issues and analysis. Journal of Business Research, V. 55, n. 5, p.349-362, 2002.

SIN, L. Y. M.; TSE, A. C. B.; YIM, F. H. K. CRM: conceptualization and scale development. EuropeanJournalof Marketing, v. 39, n. 11/12, p. 1264- 1290, 2005.

SOUZA NETO, A. F.; MELLO, S. C. B. Características dos relacionamentos estabelecidos em diferentes contextos de serviços sob a ótica do consumidor. Revista de Administração de Empresas, v. 49, n. 3, p. 309-322, 2009.

TABACHNICK, B. G.; FIDELL, L. S. Using multivariate statistics.6. ed. Boston: Pearson Allyn And Bacon, 2013.

VASCONCELOS, H.; DEMO, G. Enchant to retain: an instrumental study about the relationship between Walt Disney World Parks and its Brazilian customers. Anais do International Conference on Industrial Engineering and Operations Management, Guimarães, Portugal, 18, 2012.

VASCONCELOS, A. I. T.; MACHADO, D. Q.; ALMEIDA, S. R.; ARRUDA, D. M. O.; MATOS, F. R. N. O papel das experiências de consumo na construção da imagem das marcas: um estudo nas companhias aéreas. Revista Brasileira de Pesquisa em Turismo,v. 9, n. 1 p. 138-155, 2015. 
VAVRA, T. Marketing de relacionamento: como manter a fidelidade de clientes através do marketing de relacionamento. São Paulo: Atlas, 1993.

WILSON, E. J.; VLOSKY, R. P. Partnering relationship activities: building theory from case study research. Journal of Business Research, v. 39, n.1, p. 59-70, 1997.

ZABLAH, A. R.; BELLENGER, D. N.; \& JOHNSSTON, W. J. An evaluation of divergent perspectives on customer relationship management: towards a common understanding of an emerging phenomenon. Industrial Marketing Management, v. 33, n. 6, p. 475-489, 2004. 